\title{
Penanaman Pemahaman Seks Pranikah Bagi Siswa Melalui Layanan Informasi di Sekolah Menengah Kejuruan Telkom Pekanbaru
}

\author{
Fitra Herlinda, M. Ag \\ Universitas Islam Negeri Sultan Syarif Kasim Riau, Indonesia \\ Email: fitra.herlinda@uin-suska.ac.id
}

\begin{abstract}
This research aimed at knowing whether there was aninfluence of joining Informational Service on Personal Guidance toward student pre-marriage sex comprehension. It was a Correlation that the subjects of this research were the eleventh-grade students of Accounting and Hospitality Department. The object was theinfluence of joining Informational Service on Personal Guidance toward student pre-marriage sex comprehension. The population of this research was all students of Accounting and Hospitality Department amount 116 students. Considering the large number of population, Purposive sampling technique was used. It was obtained 35 students as samples. The technique of analyzing the data was Simple linear regression formula. Based on the research findings, it could be known thatrobserved was 0.988 with 0.000 probability level. It was obtained that $r_{\text {observed }}$ was higher than $r_{\text {table }}$ at $5 \%$ and $1 \%$ significant levels $(0.3338<0.988>0.4296)$. Based on the testing, it could be concluded that $\mathrm{H}_{\mathrm{a}}$ was accepted, and $\mathrm{H}_{\mathrm{o}}$ was rejected. It meant that there was a significantinfluence of joining Informational Service on Personal Guidance toward student pre-marriage sex comprehensionatTelecomVocational High School Pekanbaru.
\end{abstract}

Keywords:Informational Service,Personal Guidance,Pre-Marriage Sex.

\section{LATAR BELAKANG}

Informasi tentang seks penting diberikan pada siswa yang telah memasuki usia remaja, karena pada masa ini fungsi hormonal sedang meningkat dan menyebabkananak mudah terangsang dan mulai memperhatikan lawan jenisnya. Hal ini dikarenakanpada usia remaja kematangan seksual anak sudah mulai berkembang.Disamping itu perlu diketahui bahwa pada usia remaja hal yang menonjol adalahsifat mudah terpengaruhnya terhadap lingkungan dan rasa ingin tahu terhadap hal-halbaru yang dihadapinya sehingga mereka sering mencoba-coba.

Menurut Sarwono (2011) banyak faktor-faktor yang mempengaruhi seks pranikah, salah satunya ialah kurangnya informasi tentang seks itu sendiri sehingga mereka mendapatkan informasi-informasi yang salah. Hal ini disebabkan orang tua tabu membicarakan seks, dan hubungan orang tua dan anaknya sudah terlanjur jauh, sehingga anak berpaling ke sumber-sumber lain yang tidak akurat. Khususnya teman sebaya dan media.

Menurut Team Keperawatan (2009) Data menunjukkan dari usia kelas sepuluh dan sebelas, remaja mendapatkan informasi seksual / seks pranikah dari media seperti televisi $57 \%$ dan internet $60 \%$. Ini merupakan tanggung jawab kita (keluarga, sekolah, dan masyarakat) lebih memahami dan mengerti keadaan seksual yang dihadapiremaja dengan cara mengarahkannya kearah positif dan memberi informasi tentang seks. 
Melalui layanan informasi khususnya bidang bimbingan pribadi guru BK dapat memberikan pengetahuan tentang seks, bahayanya seks pranikah, dan dampak-dampak dari seks pranikah, agar siswa nantinya mengerti dan bisa mengarahkannya kearah yang positif.

Winkel mengungkapkan bahwa layanan informasi merupakan layanan yang berupaya memenuhi kekurangan individu akan informasi yang mereka perlukan, layanan informasi juga bermakna usaha-usaha untuk membekali siswa dengan pemahaman dan pembekalan tentang lingkungan hidupnya, dan tentang perkembangan anak muda. Sedangkan menurut Tohirin (2007) bidang bimbingan pribadi bimbingan yang membantu individu mengatasi masalah-masalah yang bersifat pribadi, seperti masalah fisik, motorik, sosial, emosioanal, dan seks, yang mana bimbingan pribadi dapat diberikan melalui layanan informasi.

Menurut Dewa Ketut Sukardi (2008) Layanan informasi khususnya bidang bimbingan pribadi merupakan bantuan yang diberikan kepada individu dalam hal memecahkan masalahmasalah yang sangat kompleks dan bersifat sangat rahasia sekali, untuk menghadapi pergulatan dalam batinnya sendiri, dalam mengatur diri, perawatan jasmani, pengisian waktu luang, pengaturan nafsu seksual dan sebagainya.

Mengingat pentingnya informasi tentang seks di luar nikah diberikan kepada siswa melalui pendidikan formal, tentu saja ini tidak lepas dari tugas guru BK dan merencanakan melalui program-program guru BK yang tertera didalam BK 17 plus yang mana salah satu langkah preventif yang dapat dilaksanakan yaitu melalui layanan informasi khususnya pada bimbingan pribadi.

Sekolah Menengah Kejuruan Telkom Pekanbaru merupakan salah satu sekolah yang berada di bawah naungan Yayasan Islam Riau, yang mana jumlah keseluruhan muridnya mencapai 800 murid, yang diampuh oleh satu orang guru BK profesional, dan ini sudah tentu melampaui jumlah kapasitas seorang guru BK, yang mana satu orang guru BK hanya mengampu 150 orang murid, ini sangat betolak belakang, dengan jumlah yang melampaui tersebut tentu guru BK kurang maksimal dalam memberikan layanan.

Berdasarkan studi pendahuluan yang lakukan di Sekolah Menengah Kejuruan Telkom Pekanbaru, melalui observasi dan wawancara dengan guru BK dan siswa ditemukan gejala ada siswa: pacaran di usia remaja, membutuhkan informasi tentang seks pranikah dan bahaya-bahaya seks pranikah dari sumber yang benar, merasa malu membicarakan masalah seks dengan orang tua atau guru, berpendapat berpegangan tangan saat pacaran adalah sesuatu yang biasa, mendapatkan informasi tentang seks melalui media internet dan teman sebaya, dan belum sepenuhnya memahami tentang seks pranikah, dan dampak dari seks pranikah.

Berdasarkan gejala di atas, maka permasalahan dalam tulisan ini adalah: Apakah dengan mengikuti layanan informasi berpengaruh terhadap pemahaman seks pranikah siswa di SMK Telkom Pekanbaru ?.

\section{PEMBAHASAN}

\section{Seks Pranikah}

Seks adalah segala tingkah laku yang didorong oleh hasrat seksual, baik dengan lawan jenis, maupun dengan sesama jenis. Objek seksualnya bisa orang lain, orang dalam khayalan, atau diri sendiri. Sarwono menyatakan perilaku seksual remaja dalam berpacaran ditandai dengan kegiatan, berkunjug kerumah pacar atau dikunjungi pacar, berjalan berduaan, berpegangan tangan, mencium pipi, bibir, bahkan melakukan senggema. 
Adapun menurut Sarlito W. Sarwono pranikahnya diartikan sebelum menikah. Jadi seks pranikah adalah perilaku atau kegiatan seksual yang dilakukan individu tampa melalui proses pernikahan yang resmi dan sah menurut hukum dan agama.

Muhammad Ali dan Muhammad Asrori berpendapat Seks pranikah umumnya banyak terjadi dikalangan remaja khususnya siswa-dan siswi yang tengah megalami masa pubertas. Remaja, dalam bahasa aslinya disebut adolescence, berasal dari bahasa latin adolescere yang artinya "tumbuh atau tumbuh untuk mencapai kematangan. Istilah adolescence sesungguhnya memiliki arti yang luas, mencakup kematangan mental, emosional, sosial, dan fisik.

Adapun faktor-faktor yang mempengaruhi seks pranikah yaitu:

\section{Meningkatnya Libido Seksual}

Seorang remaja menghadapi tugas-tugas perkembangan, sehubungan dengan perkembanganperkembangan fisik dan peran sosial yang terjadi pada dirinya. Tugas-tugas perkembangan itu antara lain adalah menerima kondisi fisiknya yang berubah, dalam upaya mengisi peran sosialnya yang baru, seorang remaja mendapatkan motivasinya dari meningkatnya energi seksual atau libido.

\section{Penundaan Usia Perkawinan}

Penundaan usia perkawinan dapat mempengaruhi seks pranikah, karena adanya Undang-Undang Pasal 7 Ayat 1 yang berlaku di Indonesia bahwa " Perkawinan hanya diizinkan jika pihak pria sudah mencapai umur 19 tahun dan pihak wanita sudah mencapai umur 16 tahun", dan dalam Undang-Undang lain " unntuk melangsungkan pernikahan, seorang yang belum mencapai umur 21 tahun, harus mendapat izin dari orang tua.

\section{Pergaulan yang Makin Bebas}

Kebebasan pergaulan antar jenis kelamin, dengan bebas bisa kita saksikan dalam kehidupan sehari-hari, khusunya dikota-kota, dengan adanya pergaulan yang bebas tidak menutup kemugkinan akan terjadinya seks pranikah dikalangan remaja.

Kurangnya Informasi tentang seksMelihat kenyataan saat ini. Sebenarnya cukup waktu bagi remaja untuk mempersiapkan dirinya untuk mencegah hal-hal yang tidak dikhendaki. Akan tetapi pada umumnya mereka memasuki usia remaja tampa pengetahuan yang memadai tentang seks, dan selama hubungan pacaran berlangsung pengetahuan itu bukan saja tidak bertambah. Sebaliknya, malah bertambah dengan informasi-informasi yang salah. Hal ini disebabkan orang tua tabu membicarakan seks, dan hubungan orang tua dan anaknya sudah terlanjur jauh, sehingga anak berpaling ke sumber-sumber lain yang tidak akurat. Khususnya teman sebaya dan media

Menurut Tohirin (2011) Untuk itu pemberian layanan informasi khususnya pada bimbingan pribadi oleh guru BK sangat lah penting, karena layanan informasi merupakan suatu layanan yang berupaya memenuhi kekurangan individu akan informasi yang mereka perlukan. layanan informasi juga bermakna usaha-usaha untuk membekali siswa dengan pengetahuan serta pemahaman tentang lingkungan hidupnya dan tentang perkembangan anak muda.

Adapun dampak-dampak dari seks pranikah yaitu: Sarwono mengatakan Adapun dampak negatif dari seks bebas yaitu : Berdosa ( tergolong zina dan termasuk dosa besar). Menciptakan kenangan yang buruk.Mengakibatkan kehamilan yang tidak diinginkan. Pengguguran janin/pembunuhan bayi, dan terjadinya kematian tragis. Dikucilkan dan dicemoohkan masyarakat. Hancurnya masa depan remaja. Hilangnya harga diri. Penyesalan, dan kekosongan, dan dihantui perasaan bersalah. Bayi yang dilahirkan dapat mengalami gangguan mental/jiwa saat dewasa. Penyebaran penyakit kelamin seperti virus HIV yang mematikan dan dapat menular. 


\section{Layanan Informasi}

Prayitno \& Erman Amti menjelaskan bahwa layanan informasi adalah kegiatan memberikan pemahaman kepada individu-individu yang berkepentingan tentang berbagai hal yang diperlukan untuk menjalani suatu tugas atau kegiatan atau untuk menentukan arah suatu tujuan atau rencana yang dikhendaki. Dengan demikian layanan informasi itu pertama-tama merupakan perwujudan dari fungsi pemahaman dalam bimbingan dan konseling.

Sedangkan menurut Tohirin mengungkapkan bahwa layanan informasi merupakan layanan yang berupaya memenuhi kekurangan individu akan informasi yang meereka perlukan, layanan informasi juga bermakna usaha-usaha untuk membekali siswa dengan pemahaman dan pembekalan tentang lingkungan hidupnya, dan tentang perkembangan anak muda.

Sri Hastuti juga menjelaskan bahwa layanan informasi adalah usaha untuk membekali para siswa dengan pengetahuan tentang dua fakta dibidang pendidikan sekolah, bidang pekerjaan dan bidang perkembangan pribadi-sosial. Supaya mereka dengan belajar tentang lingkungan hidupnya lebih mampu mengatur dan merencanakan kehidupannya sendiri.

Dari defenisi-defenisi diatas dapat disimpulkan bahwa layanan informasi adalah suatu kegiatan bimbingan konseling yang bertujuan untuk memberikan informasi kepada para siswa agar mereka memperoleh pemahaman dan pengetahuan mengenai lingkungan dan berbagai macam permasalahan agar mereka mampu membuat keputusan untuk merencanakan kehidupan kedepannya.

Diperlukannya layanan informasi bagi individu semakin penting mengingat kegunaan informasi sebagai acuan untuk bersikap dan bertingkah laku sehari-hari, sebagai pertimbangan bagi arah pengembangan diri, dan sebagai dasar pengambilan keputusan.

Menurut Prayitno Layanan informasi berusaha memenuhi kekurangan individu akan informasi yang mereka perlukan. Dalam layanan ini, kepada peserta layanan disampaikan berbagai informasi, informasi itu kemudian diolah dan digunakan oleh individu untuk kepentingan hidup dan perkembangannya.

Ada tiga alasan utama mengapa pemberian layanan informasi perlu diselenggarakan. Pertama, membekali individu dengan berbagai pengetahuan tentang lingkungan yang diperlukan untuk memecahkan masalah yang dihadapi berkenaan dengan lingkungan sekitar, pendidikan, jabatan, maupun sosial budaya. Dalam hal ini layanan informasi berusaha meransang individu untuk dapat secara kritis mempelajari berbagai informasi berkaitan hajat hidup dan perkembangannya. Kedua, memungkinkan individu dapat menentukan arah hidupnya "kemana ia ingin pergi". Syarat dasar untuk dapat menentukan arah hidupnya adalah apabila ia mengetahui informasi yang harus dilakukan serta bagaimana bertindak secara kreatif dan dinamis berdasarkan atas informasi-informasi yang ada. Ketiga, setiap individu adalah unik, keunikan itu akan membawakan pola-pola pengambilan keputusan dan bertindak yang berbeda-beda disesuaikan dengan aspek-aspek kepribadian masing-masing individu. Dengan ketiga alasan itu, layanan informasi merupakan kebutuhan yang amat tinggi tingkatannya, lebih-lebih apabila diingat bahwa "masa depan adalah abad informasi", maka barang siapa yang tidak memperoleh informasi, maka ia akan tertinggal dan akan kehilangan masa depan.

\section{Pengaruh Mengikuti Layanan Informasi Terhadap Pemahaman Seks Pranikah}

Informasi tentang seks penting diberikan pada siswa yang telah memasuki usia remaja, karena pada masa ini fungsi hormonal sedang meningkat dan menyebabkan anak mudah terangsang dan mulai memperhatikan lawan jenisnya. Hal ini dikarenakan pada usia remaja kematangan seksual anak sudah mulai berkembang. Disamping itu perlu diketahui bahwa pada usia remaja hal yang menonjol adalah sifat mudah terpengaruhnya terhadap lingkungan dan rasa ingin tahu terhadap hal-hal baru yang dihadapinya sehingga mereka sering mencoba-coba. 
Orang tua dalah sumber penting yang hilang dalam upaya memerangi kehamilan pada remaja dan penyakit menular seksual, namun kebanyakan remaja mengatakan bahwa mereka tidak dapat berbicara bebas dengan orang tua mereka mengenai hal-hal seksual. Survei menunjukkan bahwa sekitar 17\% pendidikan seks yang diterima remaja diperoleh dari ibu, dan hanya $2 \%$ yang diperoleh dari ayah, dan selebihnya dari teman sebaya, dan bahan bacaan.

Menurut Sarwono banyak faktor-faktor yang mempengaruhi seks pranikah, salah satunya ialah kurangnya informasi tentang seks itu sendiri sehingga mereka mendapatkan informasiinformasi yang salah. Hal ini disebabkan orang tua tabu membicarakan seks, dan hubungan orang tua dan anaknya sudah terlanjur jauh, sehingga anak berpaling ke sumber-sumber lain yang tidak akurat khususnya teman sebaya dan media.

Menurut Jhon W. Santrock dalam sebuah study yang dilakukan dinyatakan bahwa dari 1000 situs yang dikunjungi, 10\% diantaranya berorientasi seks, $40 \%$ remaja telah mengunjungi situs orang dewasa, 25\% telah mengunjungi situs yang mendukung kebencian terhadap kelompok, $12 \%$ telah mengunjungi situs dimana ia dapat memperoleh informasi mengenai cara membeli sebuah senjata api.

Menurut Team Keperawatan Data menunjukkan dari usia kelas sepuluh dan sebelas, remaja mendapatkan informasi seksual dari media seperti televisi $57 \%$ dan internet $60 \%$. Ini merupakan tanggung jawab kita (keluarga, sekolah, dan masyarakat) lebih memahami dan mengerti keadaan seksual yang dihadapiremaja dengan cara mengarahkannya kearah positif dan memberi informasi tentang seks.

Informasi yang diberikan guru BK sangatlah berguna, melalui layanan informasi siswa dapat mengetahui apa itu seks pranikah, bagaimana bahaya dan dampak yang ditimbulkan, sehingga bisa mencegah siswa ke perilaku seks pranikah, dan membuat mereka cenderung untuk menjauhi seks pranikah.

\section{Analisis Pengarub Mengikuti Layanan Informasi Terhadap Pemahaman Seks Pranikah Siswa di Sekolah Mengah Kejuruan Telkom Pekanbaru}

Untuk mengetahui apakah terdapat pengaruh layanan informasi bidang bimbingan pribadi terhadap pemahaman seks pranikah siswa kelas XII ADKP di SMK Telkom Pekanbaru, maka data akan dianalisis menggunakan regresi linier dengan menggunakan metode kuadrat terkecil dan menggunakan bantuan perangkat komputer melalui program SPSSversi 16.0 for windows. langkah yang digunakan dalam menganalis data adalah:

Uji Normalitas

Uji normalitas digunakan untuk mengetahui apakah data tersebut berasal dari populasi yang berdistribusi normal atau sebaliknya. Jika nilainya signifikan lebih besar dari 0,05 maka data tersebut normal.

Berdasarkan proses analisis dengan bantuan program SPSS 16.0 for windows maka diperoleh hasil sebagai berikut:

Tabel IV. I

Uji Normalitas

One-Sample Kolmogorov-Smirnov Test

\begin{tabular}{|l|c|}
\hline & $\begin{array}{c}\text { Unstandardize } \\
\text { d Residual }\end{array}$ \\
\hline
\end{tabular}




\begin{tabular}{|ll|r|}
\hline $\mathrm{N}$ & 35 \\
Normal Parameters $^{\mathrm{a}}$ & Mean & .0000000 \\
& Std. Deviation & 1.54415351 \\
Most Extreme & Absolute & .093 \\
Differences & Positive & .093 \\
& Negative & -.078 \\
Kolmogorov-Smirnov Z & & .548 \\
Asymp. Sig. (2-tailed) & & .925 \\
\hline
\end{tabular}

Test distribution is Normal.

Berdasarkan tabel di atas dapat diketahui bahwa nilai signifikansi sebesar 0.925 lebih besar dari 0.05 sehingga dapat disimpulkan bahwa data yang kita uji distribusi normal.

\section{Uji Linearitas}

Uji linearitas ini digunakan untuk mengetahui kelinieritas data. Hipotesis yang diuji adalah:

Ho : Distribusi data yang diteliti tidak mengikuti bentuk linier

Ha : Distribusi data yang diteliti mengikuti bentuk linier

Data Pengambilan Keputusan adalah:

Jika Probabilitas $>0.05=$ Ho diterima

Jika Probabilitas $<0.05=$ Ho ditolak

Berdasarkan proses analisis dengan menggunakan bantuan program SPSS 16.0 for windows diperoleh hasil sebagai berikut:

Tabel IV. 2

Uji Linearitas

ANOVA $^{b}$

\begin{tabular}{|c|c|c|c|c|c|}
\hline Model & $\begin{array}{l}\text { Sum of } \\
\text { Squares }\end{array}$ & $\mathrm{f}$ & $\begin{array}{r}\text { Mea } \\
\text { n Square }\end{array}$ & F & Sig. \\
\hline $\begin{array}{l}\text { Regress } \\
\text { ion }\end{array}$ & 3318.930 & & $\begin{array}{r}3318 \\
.930\end{array}$ & $\begin{array}{r}1 \\
3.513\end{array}$ & $.000^{\mathrm{a}}$ \\
\hline $\begin{array}{l}\text { Residua } \\
1\end{array}$ & 81.070 & 3 & $\begin{array}{r}2.45 \\
7\end{array}$ & & \\
\hline
\end{tabular}




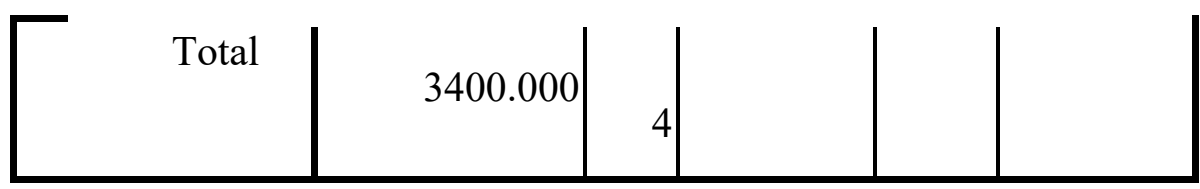

a. Predictors: (Constant),

layanan informasi

b. Dependent Variable: pemahaman seks

pranikah

Dari hasil perhitungan yang diperoleh diatas dapat diketahui bahwa, $\mathrm{F}$ hitung $=13.513$ dengan tingkat probabilitas (sig) 0.000 . maka dari itu dapat disimpulkan probabilitas $0.000<0.05$ maka Ho ditolak dan Ha diterima, sehingga data ini adalah linier.

a. Persamaan Regresi

- Tabel IV. 3

\section{- Persamaan Regresi}

\section{Coefficients $^{\mathrm{a}}$}

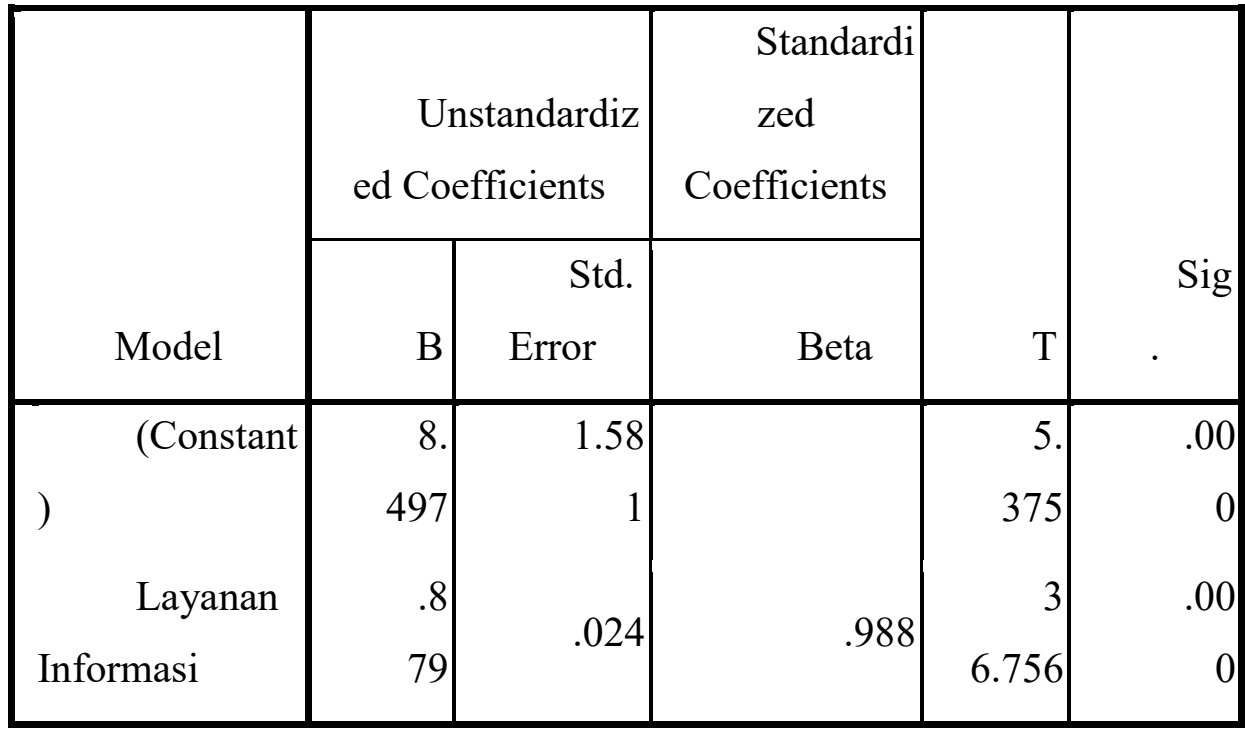

a. Dependent Variable: Pemahaman

Seks Pranikah

Berdasarkan tabel diatas dapat diperoleh persamaan regresi sebagai berikut:

$\breve{Y}=8.497+0.879$

Keterangan:

$\breve{Y}$ : Layanan informasi

a : Konstanta

b : Koefisien regresi 


\section{$\mathrm{X}$ : Pemahaman seks pranikah}

Persamaan regresi tersebut dapat dijelaskan bahwakonstanta sebesar 8.497 artinya jika pengaruh yang diperoleh dari variabel $\mathrm{X}$ nilainya adalah konstan, maka nilai variabel $\mathrm{Y}$ adalah 8.497 dan koefisien regresi variabel X 0.879 koefisien regresi bernilai positif. dengan demikian jika variabel $\mathrm{X}$ mengalami kenaikan, maka variabel Y 0.879. sehingga dapat disimpulkan bahwa ada pengaruh positif antara mengikuti layanan informasi terhadap pemahaman seks pranikah siswa.

Uji Signifikansi pengaruh mengikuti layanan informasi terhadap pemahaman seks pranikah siswa kelas XI AKDP Sekolah Menengah Kejuruan Telkom Pekanbaru.

Hipotesis dalam penelitian ini dapat dirumuskan menjadi hipotesis alternatif ( $\mathrm{Ha}$ ) dan hipotesis nihil ( Ho) sebagai berikut:

Ha: Ada pengaruh yang signifikan mengikuti layanan informasi terhadap pemahaman seks pranikah siswa kelas XI AKDP SMK Telkom Pekanbaru.

Ho: Tidak ada pengaruh yang signifikan antara mengikuti layanan informasi terhadap pemahaman seks pranikah siswa kelas XI AKDP SMK Telkom Pekanbaru.

Pengujian hipotesis tersebut dilakukan dengan bantuan SPSS 16.0 for windows dan diperoleh hasil sebagai berikut:

Tabel IV. 4

Uji Signifikansi

Correlations

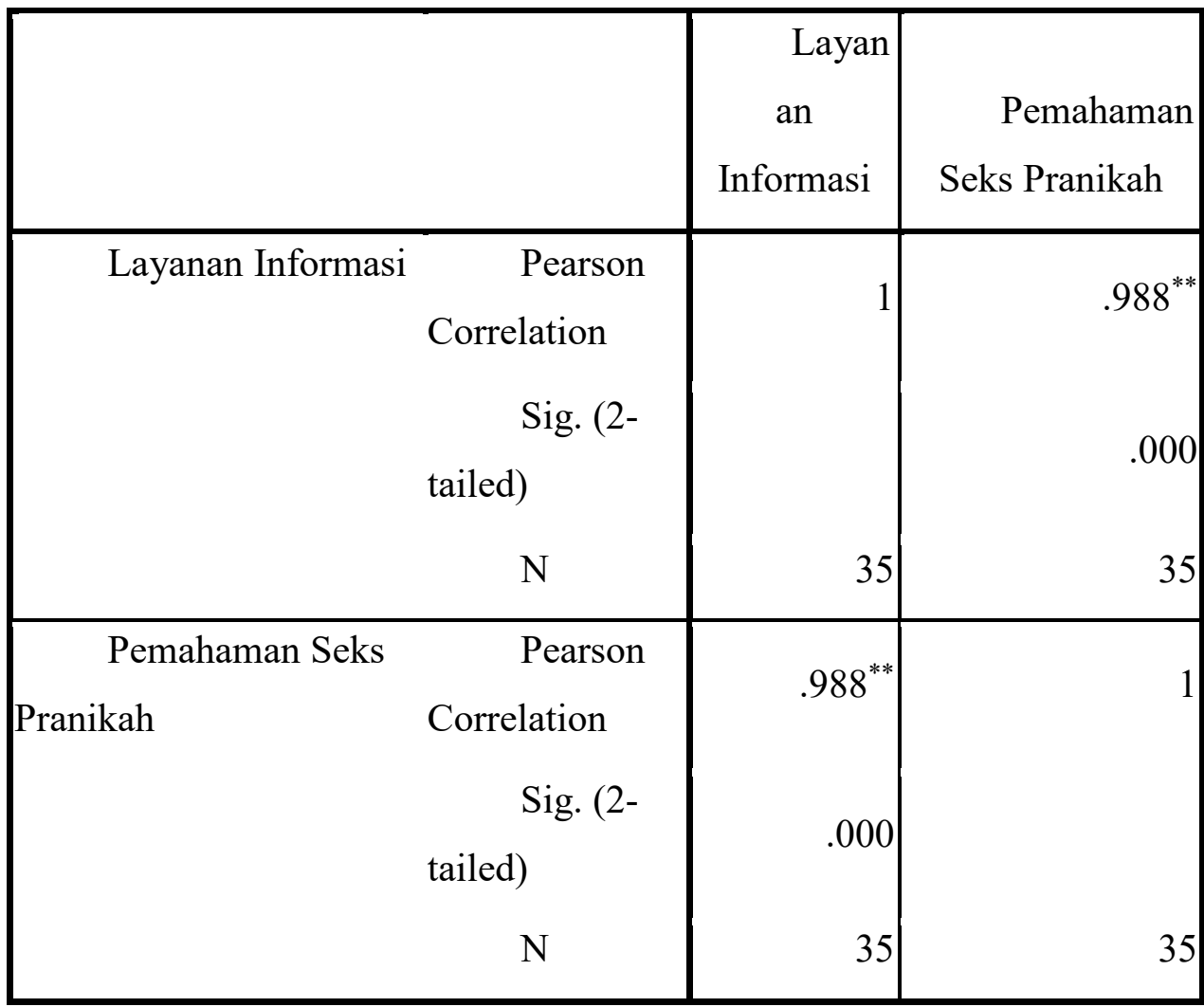

**. Correlation is significant at the 0.01 level (2-

tailed). 
Berdasarkan tabel IV. 41 diperoleh nilai $\mathrm{r}$ (Person Corelation) 0.988 dengan tingkat probabilitas 0.000. Karena probabilitas lebih kecil dari 0.05 maka Ho ditolak, sehingga terdapat pengaruh antara variabel $\mathrm{X}$ terhadap variabel $\mathrm{Y}$. Pengujian tersebut juga dapaat dilakukan dengan membandingkan $\mathrm{r}$ observasi dengan $\mathrm{r}$ tabel dengan cara sebagai berikut:

$$
\begin{aligned}
& \mathrm{df}=\mathrm{N}-\mathrm{nr} \\
& =35-2 \\
& =33
\end{aligned}
$$

Nilai df sebesar 33 diperoleh nilai $r$ tabel sebagai berikut:

rt ( tabel ) pada taraf signifikan 5\% $=0.3338$

rt ( tabel ) pada taraf signifikan $1 \%=0.4296$

Hasil tersebut menunjukkan bahwa:

ro $($ observasi $)=0.988$ bila dibandingkan $\mathrm{rt}($ tabel $)$ pada taraf signifikan $5 \%(0.988>0.3338)$ ini berarti Ha diterima. Ho ditolak.

ro $($ observasi $)=0.988$ bila dibandingkan $\mathrm{rt}$ ( tabel $)$ pada taraf signifikan 1\% $(0.988>0.4296$ ini berarti Ha diterima dan Ho ditolak.

Berdasarkan pengujian tersebut maka dapat disimpulkan bahwa Ha diterima dan Ho ditolak, hal ini berarti bahwa terdapat pengaruh yang antara mengikuti layanan informasi terhadap pemahaman seks pranikah siswa di Sekolah Menengah Kejuruan Telkom Pekanbaru.

Untuk mengetahui apakah ada pengaruh layanan terhadap pemahaman seks pranikah siswa kelas XII ADKP di SMK Telkom Pekanbaru, maka data akan dianalisis menggunakan regresi linier dengan menggunakan metode kuadrat terkecil dan menggunakan bantuan perangkat komputer melalui program SPSSversi 16.0 for windows. langkah yang digunakan dalam menganalis data adalah:

\section{Uji Normalitas}

Uji normalitas digunakan untuk mengetahui apakah data tersebut berasal dari populasi yang berdistribusi normal atau sebaliknya. Jika nilainya signifikan lebih besar dari 0,05 maka data tersebut normal.

Berdasarkan proses analisis dengan bantuan program SPSS 16.0 for windows maka diperoleh hasil sebagai berikut: 
- Tabel IV. 5

- Uji Normalitas

One-Sample Kolmogorov-Smirnov Test

\begin{tabular}{|ll|r|}
\hline & & \multicolumn{2}{|c|}{$\begin{array}{c}\text { Unstandardize } \\
\text { d Residual }\end{array}$} \\
\hline $\mathrm{N}$ & & 35 \\
Normal Parameters ${ }^{\mathrm{a}}$ & Mean & .0000000 \\
& Std. Deviation & 1.54415351 \\
Most Extreme & Absolute & .093 \\
Differences & Positive & .093 \\
& Negative & -.078 \\
Kolmogorov-Smirnov Z & & .548 \\
Asymp. Sig. (2-tailed) & & .925 \\
\hline
\end{tabular}

b. Test distribution is Normal.

Berdasarkan tabel di atas dapat diketahui bahwa nilai signifikansi sebesar 0.925 lebih besar dari 0.05 sehingga dapat disimpulkan bahwa data yang kita uji distribusi normal.

c. Uji Linearitas

- Uji linearitas ini digunakan untuk mengetahui kelinieritas data. Hipotesis yang diuji adalah:

- Ho : Distribusi data yang diteliti tidak mengikuti bentuk linier

- Ha : Distribusi data yang diteliti mengikuti bentuk linier

- Data Pengambilan Keputusan adalah:

- Jika Probabilitas $>0.05=$ Ho diterima

- Jika Probabilitas $<0.05=$ Ho ditolak

- Berdasarkan proses analisis dengan menggunakan bantuan program SPSS 16.0 for windows diperoleh hasil sebagai berikut:

- $\quad$ Tabel IV. 38

- Uji Linearitas 


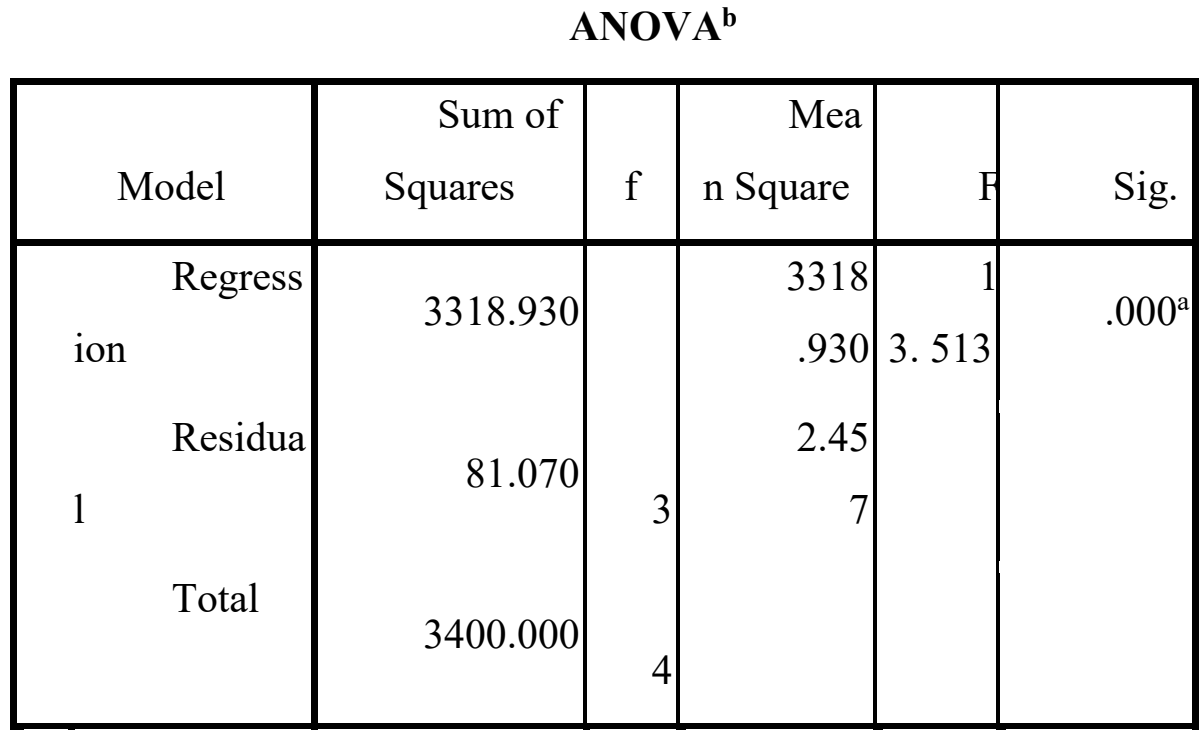

a. Predictors: (Constant),

layanan informasi

b. Dependent Variable: pemahaman seks

pranikah

Dari hasil perhitungan yang diperoleh diatas dapat diketahui bahwa, F hitung $=13.513$ dengan tingkat probabilitas (sig) 0.000. maka dari itu dapat disimpulkan probabilitas $0.000<0.05$ maka Ho ditolak dan Ha diterima, sehingga data ini adalah linier.

d. Persamaan Regresi

- Tabel IV. 39

- Persamaan Regresi

Coefficients ${ }^{\mathrm{a}}$

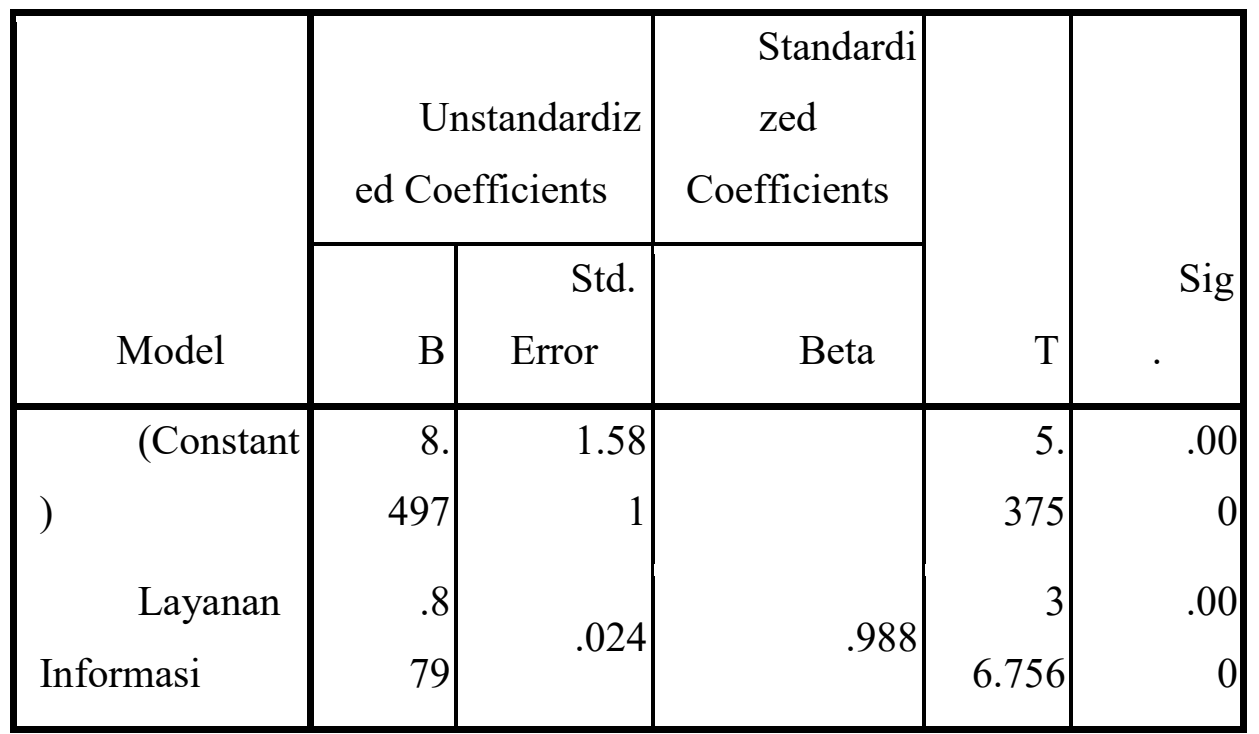




\section{Coefficients $^{\mathrm{a}}$}

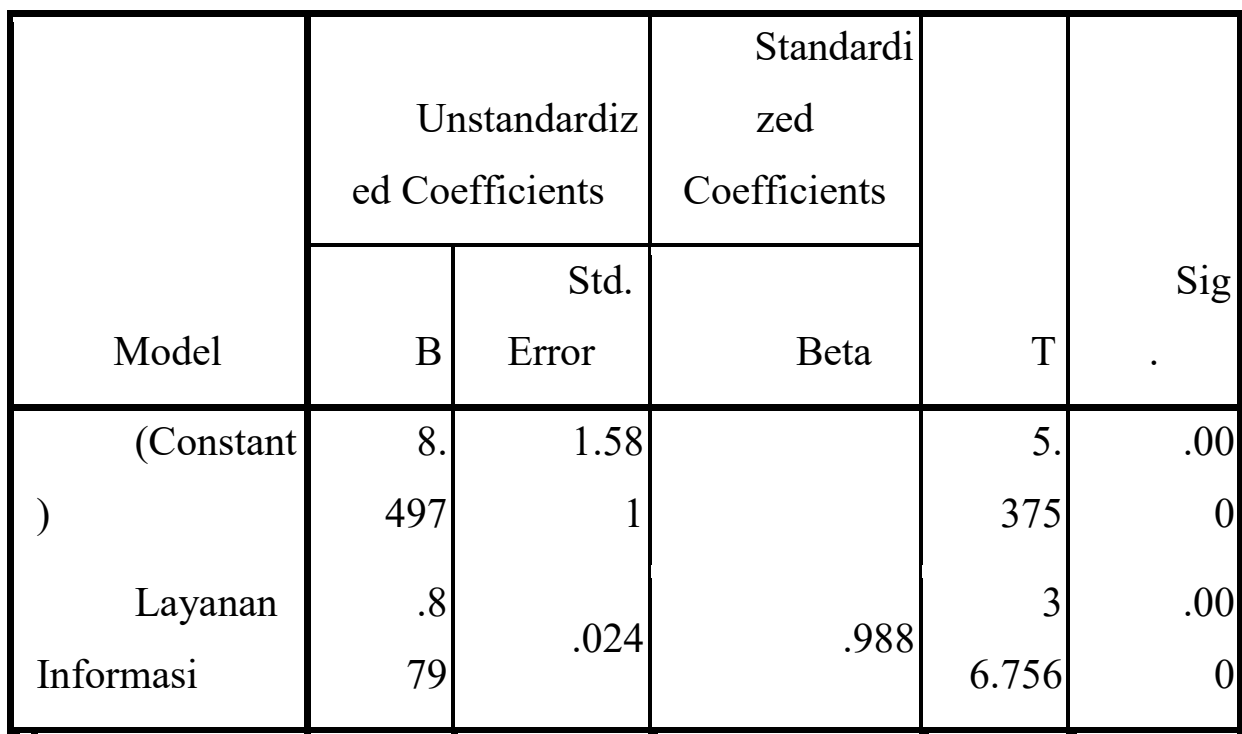

a. Dependent Variable: Pemahaman

Seks Pranikah

Berdasarkan tabel diatas dapat diperoleh persamaan regresi sebagai berikut:

$\breve{Y}=8.497+0.879$

Keterangan:

$\breve{Y}$ : Layanan informasi

a : Konstanta

b : Koefisien regresi

$\mathrm{X}$ : Pemahaman seks pranikah

Persamaan regresi tersebut dapat dijelaskan bahwakonstanta sebesar 8.497 artinya jika pengaruh yang diperoleh dari variabel $\mathrm{X}$ nilainya adalah konstan, maka nilai variabel $\mathrm{Y}$ adalah 8.497 dan koefisien regresi variabel X 0.879 koefisien regresi bernilai positif. dengan demikian jika variabel $\mathrm{X}$ mengalami kenaikan, maka variabel Y 0.879. sehingga dapat disimpulkan bahwa ada pengaruh positif antara mengikuti layanan informasi terhadap pemahaman seks pranikah siswa.

Uji Signifikansi pengaruh mengikuti layanan informasi terhadap pemahaman seks pranikah siswa kelas XI AKDP Sekolah Menengah Kejuruan Telkom Pekanbaru.

Hipotesis dalam penelitian ini dapat dirumuskan menjadi hipotesis alternatif ( $\mathrm{Ha}$ ) dan hipotesis nihil ( Ho) sebagai berikut:

Ha: Ada pengaruh yang signifikan mengikuti layanan informasi terhadap pemahaman seks pranikah siswa kelas XI AKDP SMK Telkom Pekanbaru.

Ho: Tidak ada pengaruh yang signifikan antara mengikuti layanan informasi terhadap pemahaman seks pranikah siswa kelas XI AKDP SMK Telkom Pekanbaru.

Pengujian hipotesis tersebut dilakukan dengan bantuan SPSS 16.0 for windows dan diperoleh hasil sebagai berikut: 
- Tabel IV. 40

- Uji Signifikansi

Correlations

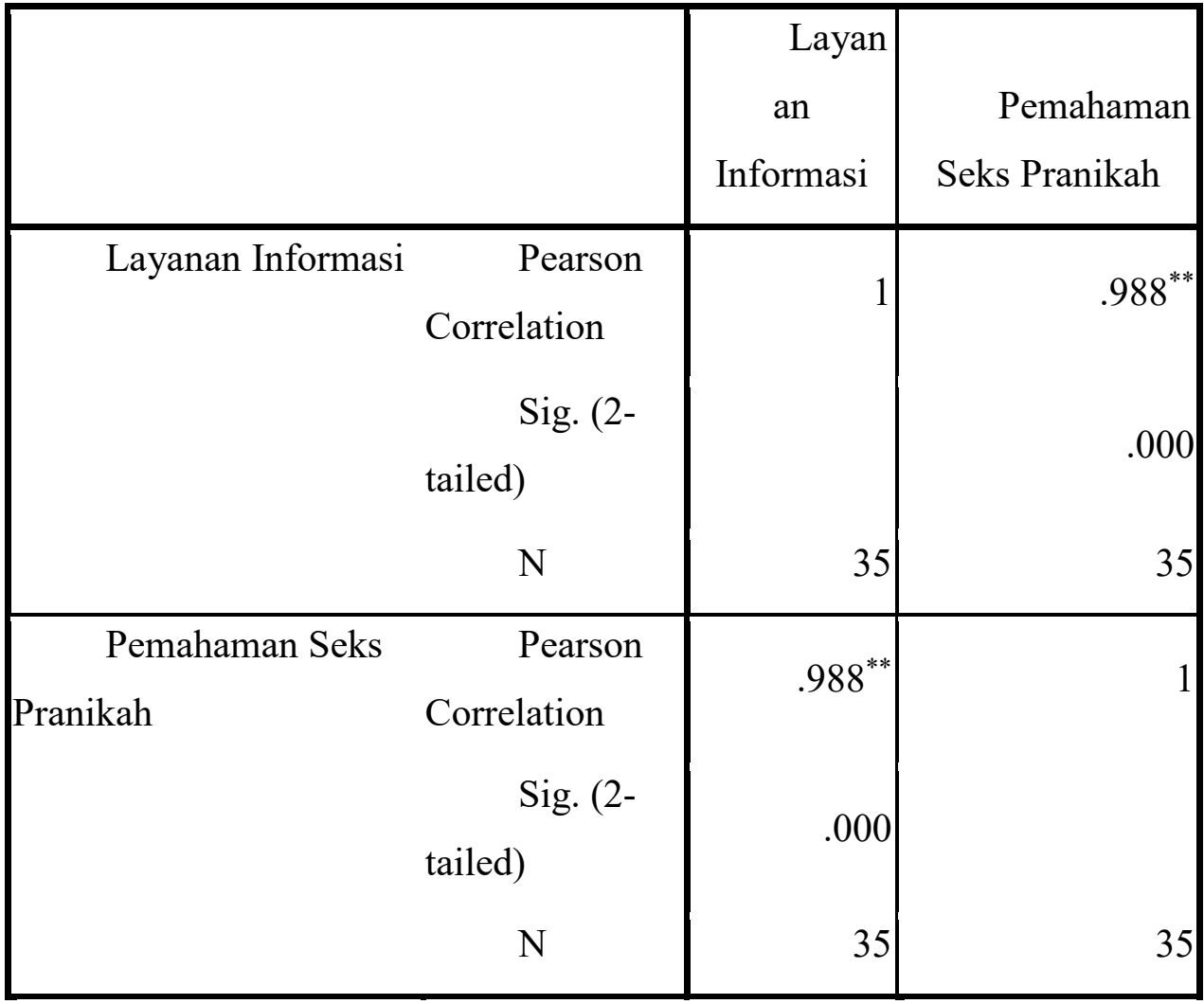

**. Correlation is significant at the 0.01 level (2-

tailed).

Berdasarkan tabel IV. 41 diperoleh nilai r (Person Corelation) 0.988 dengan tingkat probabilitas 0.000. Karena probabilitas lebih kecil dari 0.05 maka Ho ditolak, sehingga terdapat pengaruh antara variabel X terhadap variabel Y. Pengujian tersebut juga dapaat dilakukan dengan membandingkan $\mathrm{r}$ observasi dengan $\mathrm{r}$ tabel dengan cara sebagai berikut:

$$
\begin{aligned}
& \mathrm{df}=\mathrm{N}-\mathrm{nr} \\
& =35-2 \\
& =33
\end{aligned}
$$

Nilai df sebesar 33 diperoleh nilai $r$ tabel sebagai berikut:

rt ( tabel ) pada taraf signifikan 5\%=0.3338

rt ( tabel ) pada taraf signifikan $1 \%=0.4296$

Hasil tersebut menunjukkan bahwa:

ro $($ observasi $)=0.988$ bila dibandingkan $\mathrm{rt}($ tabel $)$ pada taraf signifikan $5 \%(0.988>0.3338)$ ini berarti Ha diterima. Ho ditolak.

ro $($ observasi $)=0.988$ bila dibandingkan rt ( tabel $)$ pada taraf signifikan 1\% $(0.988>0.4296$ ini berarti Ha diterima dan Ho ditolak. 
Berdasarkan pengujian tersebut maka dapat disimpulkan bahwa Ha diterima dan Ho ditolak, hal ini berarti bahwa ada pengaruh yang antara mengikuti layanan informasi terhadap pemahaman seks pranikah siswa di Sekolah Menengah Kejuruan Telkom Pekanbaru.

\section{SIMPULAN}

\section{Kesimpulan}

Berdasarkan rumusan masalah dari tuisan ini maka dapat kesimpulan bahwa mengikuti layanan informasi, berpengaruh terhadap pemahaman seks pranikah siswa di SMK Telkom Pekanbaru dapat dilihat dari angka korelasi product moment sebesar 0.988, angka ini lebih besar dari angka $\mathrm{r}$ tabel pada taraf signifikan $5 \%=0.3338$, dan pada taraf $1 \%=0.4296$. dengan tingkat probabilitas 0.000 .

\section{Saran}

Berdasarkan hasil penelitian dapat diketahui bahwa siswa yang mengikuti layanan informasi berpengaruh terhadap pemahaman seks pranikah siswa. Untuk lebih meningkatkan penelitian ini maka penulis memberikan rekomendasi sebagai berikut:

Kepada guru bimbingan konseling diharapkan meningkatkan kualitas dan kreatifitas dalam pelaksanaan layanan bimbingan konseling bidang bimbingan pribadi. Kreatifitas dari guru bimbingan dan konseling dalam memberikan informasi-informasi pada bidang pribadi sangat berguna untuk pengambilan keputusan sikap siswa.

Kepada pihak sekolah diharapkan untuk mendukung pelaksanaan setiap program bimbingan pribadi yang dilaksanakan oleh guru bimbingan konseling dari segi sarana dan prasarana dan penyediaan waktu yang cukup.

Untuk peneliti selanjutnya penelitian ini hanya meneliti satu sekolah berkenaan dengan pengaruh slayanan informasi terhadap pemahaman seks pranikah siswa. Oleh karena itu, perlu dilakukan penelitian lanjutan.

\section{DAFTAR PUSTAKA}

Dewa Ketut Sukardi, (2008). PengantarPelaksanaaProgram BK di Sekolah. Jakarta: Rineka Cipta.

Jhon W. Santrock, (2011). Masa Perkembangan Anak Children.(Edisi ke sebelas), Jakarta : Selemba Humanika.

Jhon W Santrock,(2003). Adolescence (Edisi Keenam ). Jakarta: Erlangga

Margono, (2003)Metodologi Penelitian Pendidikan. Jakarta: Rineka Cipta.

Mohammad Ali dan Muhammad Asrori, (2012).Psikologi Remaja. Jakarta: PT Bumi Aksara. 
Prayitno dan Erman Amti, (2004). Dasar-Dasar BK. Jakarta: Rineka Cipta.

Prayitno, (2004). L.1-L.9. (Seri Kegiatan Pendukung Konseling). UNPAD: FIP.

Sarlito W, Sarwono. (2011). Psikologi Remaja. Jakarta: PT Raja Grafindo Persada.

Sugiyono, (2010).Metode Penelitian Kualitatif Kuantitatif dan R\&D, Bandung: Alfabeta.

Suharsimi Arikunto,(2002)Prosedur Penelitian Suatu Pendekatan Praktek, Jakarta: Rineka Cipta.

Team Keperawatan Sikap Siswa SLTA terhadap Perilaku SeksBebas Di Lingkungan Kabupaten Tasikmalaya. Majalah Keperawatan

Unpad.(Online) Unpad. 2009.. 11(20). http://www.majalahkeperawatanunpad.org.( diakses tanggal 1 Juni 2017).

Tohirin, (2007).Bimbingan Konseling di Sekolah dan Madrasah (Berbasis Integrasi ). Pekanbar: PT Raja Grafindo Persada.

Winkel dan Sri Hastuti (2006).Bimibingan Dan Konseling di Institusi Pendidikan. Yoyakarta: Media Abadi.

Yundrik. Jahja. (2011). Psikologi Perkembangan, Jakarta: Prenada Media Group.

https://blog.uad.ac.id/imad1300001192/2014/12/09/4-bidang-bimbingan-pribadi-sosialbelajar-karir/trackback/. Diakses 02-Mei 2017. 